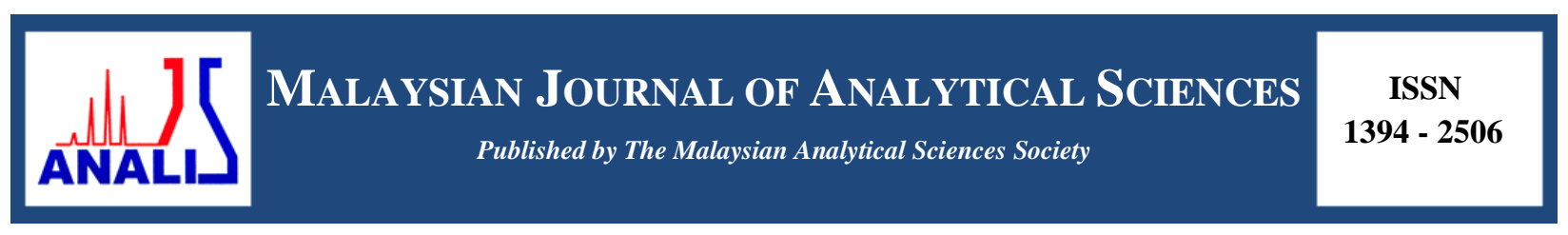

\title{
EMULSION LIQUID MEMBRANE TECHNOLOGY IN ORGANIC ACID PURIFICATION
}

\author{
(Teknologi Emulsi Membran Cecair dalam Penulenan Asid Organik) \\ Norela Jusoh $^{1}$, Norasikin Othman ${ }^{1,2 *}$, Nur Alina Nasruddin ${ }^{1}$ \\ ${ }^{I}$ Department of Chemical Engineering, Faculty of Chemical and Energy Engineering \\ ${ }^{2}$ Centre of Lipids Engineering \& Applied Research (CLEAR), Ibnu Sina Institute for Scientific and Industrial Research \\ Universiti Teknologi Malaysia, 81310 UTM Johor Bahru, Johor, Malaysia \\ *Corresponding author: norasikin@cheme.utm.my
}

Received: 14 April 2015; Accepted: 30 November 2015

\begin{abstract}
Emulsion Liquid Membrane (ELM) process have shown a great potential in wide application of industrial separations such as in removal of many chemicals, organic compounds, metal ions, pollutants and biomolecules. This system promote many advantages including simple operation, high selectivity, low energy requirement, and single stage extraction and stripping process. One potential application of ELM is in the purification of succinic acid from fermentation broth. This study outline steps for developing emulsion liquid membrane process in purification of succinic acid. The steps include liquid membrane formulation, ELM stability and ELM extraction of succinic acid. Several carrier, diluent and stripping agent was screened to find appropriate membrane formulation. After that, ELM stability was investigated to enhance the recovery of succinic acid. Finally, the performance of ELM was evaluated in the extraction process. Results show that formulated liquid membrane using Amberlite LA2 as carrier, palm oil as diluent and sodium carbonate, $\mathrm{Na}_{2} \mathrm{CO}_{3}$ as stripping agent provide good performance in purification. On the other hand, the prepared emulsion was observed to be stable up to 1 hour and sufficient for extraction process. In conclusion, ELM has high potential to purify succinic acid from fermentation broth.
\end{abstract}

Keywords: emulsion liquid membrane, purification, succinic acid, formulation, stability

\begin{abstract}
Abstrak
Proses emulsi membran cecair (ELM) telah menunjukkan potensi yang hebat dalam pelbagai aplikasi pemisahan perindustrian seperti pembuangan pelbagai bahan kimia, sebatian organik, ion logam, bahan pencemar, dan molekul biologi. Sistem ini menawarkan banyak kelebihan termasuk operasi yang mudah, sangat selektif, keperluan tenaga yang rendah, dan proses pengekstrakan dan pelucutan dalam satu peringkat. Satu potensi aplikasi ELM adalah dalam proses penulenan asid succinic daripada larutan penapaian. Kajian ini menggariskan beberapa langkah untuk membangunkan proses emulsi membran cecair dalam penulenan asid sussinik. Langkah - langkah tersebut termasuklah formulasi cecair membran, kestabilan ELM, dan pengekstrakan asik sussinik menggunakan ELM. Beberapa pembawa, pelarut, dan agen pelucutan telah ditapis untuk mencari rumusan membran yang sesuai. Selepas itu, kestabilan ELM dikaji untuk meningkatkan perolehan asid sussinik. Akhir sekali, prestasi ELM dinilai dalam proses pengekstakan. Keputusan menunjukkan bahawa rumusan cecair membran menggunakan Amberlite LA2 sebagai pembawa, minyak kelapa sawit sebagai pelarut dan natrium karbonat, $\mathrm{Na}_{2} \mathrm{CO}_{3}$ sebagai agen pelucutan memberikan prestasi yang baik dalam proses penulenan. Disamping itu, emulsi diperhatikan stabil sehingga 1 jam dan ini mencukupi untuk proses pengekstrakan. Kesimpulannya, ELM berpotensi tinggi untuk mnulenkan asid sussinik daripada proses penapaian.
\end{abstract}

Kata kunci: emulsi membran cecair, penulenan, asid sussinik, formulasi, kestabilan 


\section{Introduction}

Two fluid phases can be separated by a barrier called membrane which allow the selective permeation of solute through the barrier [1]. Membrane extraction utilizes either a porous or nonporous polymeric membrane to provide a selective barrier between the feed and the receiving phase. Instead of using solid as membrane material, it is also possible to use liquid as a membrane. Liquid membrane technology is widely applied in different potential area like wastewater treatment, textile industries, electroplating, pulp and paper, pharmaceutical, mining, semiconductor, dairy, food and beverage processing, biotechnology industries, and tanning and leather industries [2-4].

The liquid membrane extraction or commonly known as emulsion liquid membrane (ELM) was introduces as an alternative technique to the liquid-liquid extraction and to the separation by solid polymeric membranes. Basically, ELM is double emulsion produced by emulsifying two immiscible liquid phase (i.e. water droplet in oil or vice versa). Then, the resulting emulsion is dispersed into another external feed phase containing solute to be recovered or removed. The driving force of the solute transport through the membrane is simply the concentration gradient.

ELM offers numerous advantages because of high transport efficiency, economical, relatively low energy consumption, and high extraction efficiency due to large mass transfer surface area available. Besides, ELM also one of the most efficient techniques for separation and concentration process for low concentration of solute [5]. In addition, ELM process involve combination of extraction and stripping process [6]. This combination can remove the equilibrium limitation between the organic and aqueous phase. Besides, with the use of appropriate carrier for transport mechanism, specific molar recognition can be achieved.

An ELM process includes four main steps: (1) emulsification, (2) dispersion and extraction, (3) settling, and (4) demulsification (breaking of the emulsion). In the first step, emulsion is prepared by emulsifying internal phase and membrane phase. Then, the prepared emulsion is dispersed into the external feed phase containing solute to be extracted. After that, settling process is allowed to occur to separate emulsion and feed solution. Then, the membrane phase is recovered by demulsification process.

One potential application of ELM is in the purification of succinic acid from fermentation broth. Generally, succinic acid fermentation broth contains many components especially acetic acid as major by-product. Therefore, in this study, an ELM process was developed for selective separation of succinic acid from simulated solution. Important aspects regarding the ELM process is its formulation in terms of the emulsification procedure, the choice of surfactants, carrier, stripping agent and diluent, which decide whether the process is successful or not. Besides that, stability also plays an important role for successful ELM process. The emulsion should be stable enough to resist leakage during extraction, but not too stable so that the emulsion can easily demulsified.

This paper will present the investigation of liquid membrane component selection, stability study and several parameter of succinic acid extraction such as stripping agent concentration, carrier concentration and treat ratio.

\section{Materials}

\section{Materials and Methods}

Amberlite LA2 as carrier was obtained from Merck Company. Amberlite LA2 used, was mixture of straight-chain secondary amine mixture $(374 \mathrm{~g} / \mathrm{mol}$ ). Trioctylamine (TOA) (>93\% assay) and tridodecylamine (TDA) (>95\% assay) were purchased from Merck. Kerosene as diluent was purchased from Sigma Aldrich. Palm oil, also as diluent used in this study was ordinary cooking oil (BURUH) acquired from supermarket. Sodium hydroxide $(\mathrm{NaOH})\left(98 \%\right.$ assay) was purchased form J.T. Baker, while Sodium carbonate, $\mathrm{Na}_{2} \mathrm{CO}_{3}(99.5 \%$ assay) was purchased from Merck. Sorbitan Monooleate (Span 80) (with more than $60 \%$ oleic acid composition) as surfactant was purchased from Sigma Aldrich. Polyethylene glycol sorbitan monooleate (Tween 80) and Cocamide diethanolamine (DEA) was purchased from Sigma Alderich and Chemicalland21 respectively. In addition, succinic acid (SA) (99.0 \% assay) and acetic acid (AA) (99.7 \% assay) were purchased from Sigma Aldrich and J.T. Baker, respectively. All these solutions and reagents were used directly as received without further purification. 


\section{Methods}

In formulation, ELM components including carrier, diluent and stripping agent was screened by liquid-liquid extraction process. The experiment was conducted by mixing an equal volume of organic solution and with simulated aqueous feed solution at $320 \mathrm{rpm}$ using mechanical shaker. The solution was then poured carefully into separating funnel for phase separation. Sample of aqueous phase at the bottom was taken for succinic and acetic acid concentration measurement. Similar procedures was repeated for screening diluent and stripping agent. Extraction and stripping performance was evaluated using Equation 1 and 2 respectively.

The selected formulation was then used to study ELM stability. An equal volume of liquid membrane and stripping solution was emulsified at $5000 \mathrm{rpm}$ using homogenizer. The emulsion formed was transferred into measuring cylinder and then stored at room temperature. The volume of different phase separated was recorded as a function of time. Similar procedure was repeated for different parameter.

In extraction study, the prepared emulsion was dispersed into feed phase of simulated succinic acid solution. The mixture was then agitated at $600 \mathrm{rpm}$ for 3 minutes using a motor stirrer. The mixture was then separated in separating funnel. The aqueous phase at the bottom was taken for analysing. The performance of extraction was evaluated using Equation 1.

$$
\begin{aligned}
& \text { Amount extract }(g / l)=\frac{[A]_{i(a q)}-[A]_{f(a q)}}{[A]_{i(a q)}} \\
& \text { Amount } \operatorname{strip}(g / l)=[A]_{f s(a q)}
\end{aligned}
$$

where, $[A]_{i(a q)}$ is the initial acid concentration in external aqueous phase $(\mathrm{g} / \mathrm{l}) ;[A]_{f(a q)}$ is the acid concentration in aqueous extrenal phase after extraction $(\mathrm{g} / \mathrm{l}) ;[A]_{f s(a q)}$ is the acid concentration in aqueous stripping phase after stripping $(\mathrm{g} / \mathrm{l})$.

Besides that, distribution ratio (D) and separation factor $(\alpha)$ for the extraction of succinic and acetic acid were determined using Equation 3, 4, and 5.

$$
\begin{aligned}
D_{S A} & =\frac{[S A]_{\text {org }}}{[S A]_{a q}} \\
D_{A A} & =\frac{[A A]_{\text {org }}}{[A A]_{a q}} \\
\alpha_{S A} & =\frac{D_{S A}}{D_{A A}}
\end{aligned}
$$

where $D_{S A}$ is the distribution ratio of succinic acid; $D_{A A}$ is the distribution ratio of acetic acid; $\alpha_{S A / A A}$ is the separation factor of succinic over acetic acid.

\section{ELM formulation for Succinic Acid}

\section{Results and Discussion}

The experimental results for liquid membrane component screening are shown in Table 1. The first parameter in liquid membrane formulation is carrier screening. The selection of suitable carrier is very crucial for the ELM system to perform well and selectively form complex with desired solute. Secondary or tertiary amine are generally typical carrier for carboxylic acid [6]. In this study, TOA, TDA and Amberlite LA2 from amine group were used to extract succinic acid. The current study clearly shows that Amberlite LA2 gives the best performance for succinic acid extraction (19.98 g/l) compared to TOA (10.99 g/l) and TDA $(3.20 \mathrm{~g} / \mathrm{l})$. This is due to the Amberlite LA2 is one of the secondary amine, while TOA and TDA are both tertiary amine. Secondary amine can easily form complex with succinic acid and form ammonium salt. The process of complex formation involved the ion pair 
association between the acid radical and the alkylammonium cation. Since Amberlite LA2 is a secondary amine, it can easily react with acid radical by losing the $\mathrm{H}$ bonding. This finding in line with the results found by Ricker (1978) who reported that the secondary amine shows better extractability compared to tertiary amine. Besides, highest value of separation factor was obtained using Amberlite LA2 as the carrier. This means that Amberlite LA2 not only can extract high amount of succinic acid, but it also selectively forms complex with succinic acid over acetic acid. Therefore, the use of Amberlite LA2 was preferred for the ELM formulation to separate succinic and acetic acid and used in the following section.

Table 1. Results of liquid membrane component screening

\begin{tabular}{|c|c|c|c|c|}
\hline Parameters & Variables & $\begin{array}{c}\text { SA extract } \\
(\mathrm{g} / \mathrm{l})\end{array}$ & $\underset{(\mathrm{g} / \mathrm{l})}{\text { AA extract }}$ & Selectivity, $\alpha_{S A / A A}$ \\
\hline \multirow[t]{3}{*}{ Carrier } & TOA & 10.99 & 1.40 & 2.15 \\
\hline & TDA & 3.20 & 0.48 & 8.48 \\
\hline & Amberlite LA2 & 19.98 & 0.42 & 23.81 \\
\hline \multirow[t]{6}{*}{ Kerosene/palm oil \% } & $100 / 0$ & 18.45 & 0.07 & 134.73 \\
\hline & $70 / 30$ & 20.89 & 0.70 & 17.79 \\
\hline & $50 / 50$ & 20.11 & 0.42 & 27.73 \\
\hline & $30 / 70$ & 22.22 & 0.28 & 57.82 \\
\hline & $0 / 100$ & 21.39 & 0.41 & 34.10 \\
\hline & & $\begin{array}{l}\text { SA stripped } \\
(\mathrm{g} / \mathrm{l})\end{array}$ & & \\
\hline \multirow[t]{2}{*}{ Stripping agent } & $\mathrm{NaOH}$ & 7.58 & - & - \\
\hline & $\mathrm{Na}_{2} \mathrm{CO}_{3}$ & 16.34 & - & - \\
\hline
\end{tabular}

The influence of diluents on separation of succinic and acetic acid also tabulated in Table 1. The present study shows that similar amount of succinic acid was extracted using different composition of kerosene and palm oil between $18-22 \mathrm{~g} / \mathrm{l}$ of succinic acid. The results indicate that the composition of kerosene and palm oil did not give much effect on succinic acid extraction. Nevertheless, there was a really large different on the selectivity of succinic acid, where kerosene gives the best selection of succinic acid with 134.73 separation factor value. However, kerosene is not environmentally friendly and the toxicity effect of kerosene will be harmful to human. Hence, it is highly desirable to replace it with another material, such as palm oil. According to the results in Table 1, the combination of 30/70 kerosene to palm oil also leads to high separation factor (57.82) followed by a comparatively separation factor using pure palm oil (34.10). The 30/70 kerosene to palm oil provide larger separation factor, but the combination can complicate the extraction process and kerosene is still being used although in a small proportion. Therefore pure palm oil is selected as possible diluent in this study. This is because the valuable property in palm oil over kerosene seen as renewable, nontoxic and readily available. Hence, pure palm oil is considered as diluent in next study.

In the ELM system, the succinic acid extraction is governed by $\mathrm{pH}$ difference between the external feed and internal receiving phase. Therefore, alkaline solution such as $\mathrm{NaOH}$ and $\mathrm{Na}_{2} \mathrm{CO}_{3}$ were screened in this study as stripping agent for succinic acid extraction. The results indicate there is almost no acetic acid stripped in the process due to very small amount of acetic acid is extracted in the loaded organic phase. The amount of succinic acid stripped using $\mathrm{Na}_{2} \mathrm{CO}_{3}$ is $16.34 \mathrm{~g} / \mathrm{l}$ compared to $\mathrm{NaOH}$ which is only $7.59 \mathrm{~g} / \mathrm{l}$. This is because $\mathrm{Na}_{2} \mathrm{CO}_{3}$ dissociates, and forms 2 moles of sodium ion in comparative to $\mathrm{NaOH}$ that gives only 1 mol. Therefore, more succinic acid will be stripped using $\mathrm{Na}_{2} \mathrm{CO}_{3}$. The result of this study seems to be consistent with other research, who reported that $\mathrm{Na}_{2} \mathrm{CO}_{3}$ show better performance than $\mathrm{NaOH}$ in stripping process of succinic acid [8]. 
ELM stability study: Effect of organic to internal ratio

Organic to internal phase ratio is important in order to achieve optimal emulsion stability. Table 2 represents stability of prepared emulsion showing various stage of phase separation. The most unstable emulsion was formed by $1 / 1$ organic to internal ratio where the internal droplets dispersion did not last long and about $27 \%$ of aqueous phase was separated just within 10 minutes. This is because the nature property of the palm oil and the existing natural surface-active agent called stearin influence the oil/water interface and modify the structure of the interfacial film and hence affect its stability [9]. Therefore, less droplets was formed for $1 / 1$ ration. Increasing the ratio of $\mathrm{O} / \mathrm{I}$ to $3 / 1$ cause increasing in emulsion stability due to increase in the membrane phase layer around the internal droplets [10]. Besides, increasing the organic fraction will also increase the surfactant content in the emulsion, results in better droplet formation, increase mechanical resistance of the membrane and prevent coelescence of the dispersed droplet. Thus, more stable emulsion with greater amount of droplets was formed. Hence, 3/1 of O/I ratio is highly preferable to produce a stable emulsion.

Table 2. Effect of organic to internal ratio on emulsion stability

\begin{tabular}{lccc}
\hline \multirow{2}{*}{ O/I ratio } & \multicolumn{3}{c}{ Aqueous phase separated (\%) } \\
\cline { 2 - 4 } & $\mathbf{1 0} \mathbf{~ m i n}$ & $\mathbf{3 0} \mathbf{~ m i n}$ & $\mathbf{6 0} \mathbf{~ m i n}$ \\
\hline $1: 1$ & 26 & 36 & 40 \\
$2: 1$ & 10 & 16 & 30 \\
$3: 1$ & 0 & 1 & 5 \\
\hline
\end{tabular}

\section{Effect of homogenizer speed}

Application of mechanical energy can make one of the liquid breaks into droplets and disperse in the other and form emulsion. The influence of homogenizer speed on the performance of water in oil emulsion stability was presented in Table 3. Result indicates that the water in oil emulsion stability significantly increase as increasing homogenizer speed from 5000 to $7000 \mathrm{rpm}$. This is because increasing the homogenizer speed produce higher number of droplets with greater interfacial area, thus stabilize the emulsion. A study by Sulaiman et al. [11] also found that higher homogenizer speed increase emulsion stability. Further increase the speed to 9000 shows that the stability is lower than that of $7000 \mathrm{rpm}$. This is due to the droplets tend to coalesce among each other, thus enlarging their size which leading to the breakage of the droplet. At $12000 \mathrm{rpm}$ homogenizer speed, a highly viscous, "mayonnaise-like" emulsion was formed. The reason for this is due to foaming mechanism, where air-bubbles are incorporated into the emulsion phase, and lead to a more rigid system. Therefore, homogenizer speed at $7000 \mathrm{rpm}$ is preferable in this study in producing stable emulsion.

Table 3. Effect of homogenizer speed on emulsion stability

\begin{tabular}{lccc}
\hline \multirow{2}{*}{$\begin{array}{c}\text { Homogenizer speed } \\
(\mathbf{r p m})\end{array}$} & \multicolumn{3}{c}{ Aqueous phase separated (\%) } \\
\cline { 2 - 4 } & $\mathbf{1 0}$ min & $\mathbf{3 0}$ min & $\mathbf{6 0}$ min \\
\hline 5000 & 0 & 0.96 & 7.69 \\
7000 & 0 & 0.96 & 3.85 \\
9000 & 0 & 0.96 & 5.77 \\
12000 & 0 & 0.96 & 0.96 \\
\hline
\end{tabular}




\section{Effect of emulsifying time}

Table 4 demonstrate the effect of emulsification time on water in oil emulsion stability. For 3 minutes emulsification time, about $2 \%$ of aqueous phase was separated from the emulsion in 10 minutes storage. This indicates that short emulsifying time produce unstable emulsion because of the organic membrane and aqueous internal solution was not well homogenized. Additions of emulsification time to 5 minutes produce more stable emulsion, where it starts to break after 30 minutes. This is due to smaller internal droplets formed, thus leading to stable emulsion because smaller droplets take more time to coalesce [12]. However, an extending the emulsification time up to 10 minutes and above decrease the stability of water in oil emulsion due to high shear exposure and causing emulsion breakage. The breakage phenomena because of prolonged emulsification time also observed by Othman et al. [13]. Thus, 5 minutes emulsification time is sufficient for the production of most stable emulsion.

Table 4. Effect of emulsifying time on emulsion stability

\begin{tabular}{cccc}
\hline \multirow{2}{*}{$\begin{array}{c}\text { Emulsifying time } \\
(\text { min })\end{array}$} & \multicolumn{3}{c}{ Aqueous phase separated (\%) } \\
\cline { 2 - 4 } & $\mathbf{1 0}$ min & 30 min & $\mathbf{6 0}$ min \\
\hline 3 & 2 & 15 & 21 \\
5 & 0 & 0.96 & 3.85 \\
10 & 2 & 15 & 20 \\
15 & 4 & 13 & 21 \\
20 & 0 & 15 & 22 \\
\hline
\end{tabular}

\section{Effect of surfactant blend}

Surfactant blend have synergistic effects in enhancing emulsion stability. Compared to individual emulsifiers, appropriate surfactant combination produce a greatly enhanced emulsion stability [9]. Basically, the addition of a co-surfactant can further reduce interfacial tension, also through adsorbing in the w/o interface thereby minimizing the repulsion of the hydrophilic head-groups of the surfactants, which contributes to a more efficient packing of the surfactants at the interface and reduces water droplet size. Result shows better stability was observed when HLB is increased. This indicate that Span 80 is compatible with Tween 80 . This is due to similarity structure between both surfactant, since Tween 80 is a derivative from Span 80. Due to the compatibility structure, the film of Span 80 be better solvent for the Tween 80 on the mixed film, therefore form a phase that resist breakage. Hence, the emulsion is more stable. Figure 4 shows emulsion at HLB 8 and HLB 15 remain unseparated. However, emulsion at HLB 15 using only Tween 80 favours oil in water emulsion. Thus, combination of Span 80 and Tween 80 at HLB 8 will be considered for the next experiment.

Table 5. Effect of surfactant blend on emulsion stability

\begin{tabular}{cccc}
\hline \multirow{2}{*}{ HLB } & \multicolumn{3}{c}{ Aqueous phase separated (\%) } \\
\cline { 2 - 4 } & $\mathbf{1 0}$ min & $\mathbf{3 0}$ min & $\mathbf{6 0}$ min \\
\hline 4.3 & 0 & 18 & 20 \\
5 & 0 & 0 & 4 \\
6 & 0 & 17 & 20 \\
7 & 0 & 12 & 18 \\
8 & 0 & 0 & 0 \\
15 & 0 & 0 & 0 \\
\hline
\end{tabular}




\section{ELM extraction study}

The experimental results for succinic acid extraction efficiency are shown in Table 6. Effect of stripping agent concentration is shown in Table 6 varying from 0.01 to $2 \mathrm{M}$ of $\mathrm{Na}_{2} \mathrm{CO}_{3}$. The amount of succinic acid extracted increase when stripping agent concentration was increase from 0.01 to $0.5 \mathrm{M}$. The highest succinic acid extracted was $31.5 \mathrm{~g} / \mathrm{L}$. This is because of the tendency of the internal phase to strip succinic acid was increased and this delays the accumulation of succinic complex in the membrane layer. Further increase in $\mathrm{Na}_{2} \mathrm{CO}_{3}$ concentration reduces succinic acid extraction performance. This might be due to leakage of the succinic acid extracted and internal stripping agent through the membrane to the external. On the other hand, highest selectivity was obtained when using $0.50 \mathrm{M} \mathrm{Na}_{2} \mathrm{CO}_{3}$. It shows that at this stripping agent concentration, high amount of succinic acid was extracted. Furthermore, the system favors succinic acid than acetic acid to be extracted. Hence, $0.5 \mathrm{M} \mathrm{Na}_{2} \mathrm{CO}_{3}$ was selected as the best stripping agent concentration in this process.

Table 6. Results on succinic acid extraction

\begin{tabular}{lcccr}
\hline Parameters & Variables & $\begin{array}{c}\text { Amount of succinic acid } \\
\text { extracted }(\mathbf{g} / \mathbf{l})\end{array}$ & $\begin{array}{c}\text { Amount of acetic acid } \\
\text { extracted }(\mathbf{g} / \mathbf{l})\end{array}$ & $\begin{array}{c}\text { Selectivity } \\
\boldsymbol{\alpha}_{\text {SA/AA }}\end{array}$ \\
\hline $\mathrm{Na}_{2} \mathrm{CO}_{3}(\mathrm{M})$ & 0.01 & 2.12 & 2.21 & 0.20 \\
& 0.10 & 2.51 & 2.96 & 0.18 \\
& 0.50 & 31.54 & 1.75 & 15.02 \\
& 1.00 & 9.19 & 2.45 & 1.08 \\
& 2.00 & 3.49 & 2.98 & 0.26 \\
Amberlite & 0.005 & 7.79 & 3.63 & 0.50 \\
LA2 (M) & 0.05 & 33.79 & 3.96 & 15.79 \\
& 0.50 & 31.97 & 3.11 & 14.24 \\
& 1.00 & 18.38 & 2.48 & 3.16 \\
Treat ratio & $1: 1$ & 32.45 & 1.38 & 43.95 \\
& $1: 2$ & 33.57 & 3.72 & 16.34 \\
& $1: 3$ & 33.79 & 0.57 & 184.83 \\
& $1: 4$ & 35.02 & 4.29 & 21.94 \\
& $1: 5$ & 28.47 & 0.76 & 41.28 \\
\hline
\end{tabular}

Besides that, Table 6 also shows effect of carrier concentration on succinic acid extraction. Succinic acid was slightly extracted when $0.005 \mathrm{M}$ of Amberlite LA2 was used. This indicates amount of carrier was insufficient for extraction process. Increasing the Amberlite LA2 concentration to 0.05 increase the succinic acid extraction up to $33.8 \mathrm{~g} / \mathrm{L}$ from $40 \mathrm{~g} / \mathrm{L}$ succinic acid solution. An increased in succinic acid extraction occur due to the fact that the concentration of carrier in the organic membrane phase phenomenologically increases the solute concentration at the interface and thus increasing the driving force for extraction. However, the extraction performance was reduced when Amberlite concentration increased beyond $0.05 \mathrm{M}$. This is due to excess of free carrier in the organic membrane phase. The excessive concentration of carrier cause higher viscosity of membrane, thus reduce the mass transfer of solute into the internal phase. On the other hand, highest selectivity at 15.79 was obtained at $0.05 \mathrm{M}$ Amberlite LA2 concentration, which means succinic acid is the most favorable compared to acetic acid under this condition. Therefore, $0.05 \mathrm{M}$ Amberlite LA2 was chosen as the optimum carrier concentration due to highest amount of succinic acid extracted and highest selectivity.

This study also varies treat ratio from 1:1 to 1:5. The amount of succinic acid extracted was slightly increased from treat ratio $1: 1$ to $1: 4$. At high treat ratio (1:1 to $1: 2)$, larger mass transfer area can be obtained because higher number of emulsion globule was formed. However, with the help of surfactant hydration, this condition cause 
continuous water movement into the internal aqueous phase and leads to emulsion breakage. This breakage therefore reduce succinic acid extraction at high treat ratio. This results is in line with Sulaiman et al. [11], who reported emulsion breakage occur at high treat ratio. Further reducing the treat ratio to 1:5 reduce the succinic acid extraction performance because of the reduction in the dispersibility of the emulsion. This cause smaller mass transfer surface area. As a result, the extraction efficiency shows a decreasing trend. Besides that, succinic acid extraction also may be reduced due to the emulsion breakage, owing to the increasing osmotic pressure difference between the external and ELM phase. Despite the highest succinic acid extracted when treat ratio 1:4 is applied, result of shows that the value is smaller than selectivity in treat ratio 1:3. This indicates that more acetic acid also extracted in the system. In addition, the emulsion breakage also higher compared to 1:3. Hence, 1:3 of treat ratio was selected as optimum condition.

\section{Conclusion}

The finding of this study provides an approach for selective extraction of succinic acid toward acetic acid. It can be concluded the best liquid membrane was formulated using Amberlite LA2 as carrier, palm oil as diluent, and $\mathrm{Na}_{2} \mathrm{CO}_{3}$ as stripping agent. Besides, all the parameter has shown a significant effect on the stability of water in palm oil emulsion. The most stable emulsion was recorded at $7000 \mathrm{rpm}$ homogenizer speed, 5 minute emulsification time, and $3 \%$ (w/v) span 80, and HLB value of 8 with combination of Span 80 and Tween 80. Meanwhile, up to $33.9 \mathrm{~g} / \mathrm{L}$ succinic acid was extracted under promising conditions which are $0.5 \mathrm{M} \mathrm{Na}_{2} \mathrm{CO}_{3}, 0.05 \mathrm{M}$ Amberlite LA2, and 1:3 treat ratio.

\section{Acknowledgement}

The authors would like to acknowledge the Ministry of Higher Education (MOHE), Universiti Teknologi Malaysia (RU Research Grant; GUP: Q.J130000.2544.04H47, and Centre of Lipids Engineering and Applied Research (CLEAR) for financial support to make this research possible.

\section{References}

1. Ho, W. S. and Kamalesh, K. S. (1992). Membrane Handbook. New York: Chapman \& Hall.

2. Othman, N., Noah, N. F. M., Harruddin, N., Abdullah, N. A. and Bachok, S. K. (2014). Selective extraction of palladium from simulated liquid waste solution by emulsion liquid membrane process using D2EHPA as a mobile carrier. Jurnal Teknologi. 69(9): 1 - 4.

3. Ooi, Z.-Y., Harruddin, N. and Othman, N. (2015). Recovery of kraft lignin from pulping wastewater via emulsion liquid membrane process. Biotechnology Progress. 31(5): 1305 - 1314.

4. Araki, T. and H. Tsukube (1990). Liquid Membranes: Chemical Applications. Boca Raton, FL: CRC Press.

5. Othman, N., H. Mat, and M. Goto (2005). Selective extraction of silver from liquid photographic waste. Solvent Extraction Research and Development 12: 27 - 34.

6. Hong, Y., Hong, W. and Han, D. (2001). Application of reactive extraction to recovery of carboxylic acids. Biotechnology and Bioprocess Engineering. 6(6): 386 - 394.

7. Ricker, N. L. (1978). Recovery of Carboxylic Acids and Related Organic Chemicals from Wastewater by Solvent Extraction. University of California: Berkeley.

8. Lee, S. C. (2011). Extraction of succinic acid from simulated media by emulsion liquid membranes. Journal of Membrane Science. 381(1-2): 237 - 243.

9. Chow, M. C. and Ho, C. C. (1996). Properties of palm-oil-in-water emulsions: Effect of mixed emulsifiers. Journal of the American Oil Chemists' Society. 73(1): 47 - 53.

10. Jilska, M. P. and Geoff, W. S. (2008). Use of Emulsion Liquid Membrane Systems in Chemical and Biotechnological Separations, in Handbook of Membrane Separations. CRC Press. pp. 709 - 740.

11. Sulaiman, R. N. R., Othman, N. and Amin, N. A. S. (2014). Emulsion liquid membrane stability in the extraction of ionized nanosilver from wash water. Journal of Industrial and Engineering Chemistry. 20(5): $3243-3250$.

12. Sabry, R., Hafez, A., Khedr, M. and El-Hassanin, A. (2007). Removal of lead by an emulsion liquid membrane: Part I. Desalination. 212(1-3): 165 - 175.

13. Othman, N., Mili, N., Idris, A. and Zailani, S. N. (2012). Removal of Dyes from Liquid Waste Solution: Study on Liquid Membrane Component Selection and Stability. Sustainable Membrane Technology for Energy, Water, and Environment. pp. 221-229. 